\title{
Pengukuran dan Pemetaan Tingkat Kebisingan pada Area Produksi
}

\section{Noise Level Measurement and Mapping in Area Productions}

\author{
Nukhe Andri Silviana*1), Ninny Siregar2) , Marali Banjarnahor ${ }^{3)}$ dan Sirmas Munte ${ }^{4)}$ \\ Program Studi Teknik Industri, Fakultas Teknik. Universitas Medan Area.
}

Diterima: November 2021; Disetujui: November 2021; Dipublikasi: November 2021;

*Coresponding author : nukheandri@staff.uma.ac.id

\begin{abstract}
Abstrak
Dalam kegiatan operasional PT. Y bergerak dalam produksi Fatty Alcohol, berpotensi menghasilkan kebisingan yang diperoleh dari mesin dalam pembuatan Fatty Alcohol. Kebisingan yang terjadi pada area produksi berpengaruh pada kesehatan dan kenyamanan operator saat bekerja. Penelitian ini bertujuan untuk mengetahui tingkat kebisingan, lama waktu pemaparan, area paparan kebisingan dan analisis penyebab kebisingan serta usulan pengendalian kebisingan dilantai produksi. Metode pengukuran kebisingan mengacu pada metode noise mapping serta instrument sound level meter. Data yang diperoleh kemudian diolah menjadi peta kontur dengan variasi warna hijau, kuning, orange dan merah melalui Software surfer 16. Hasil penelitian menunjukkan tingkat kebisingan tertinggi sebesar 92,9 dB dan tingkat kebisingan terendah sebesar 83,0 dB. Berdasarkan hasil perhitungan menggunakan persamaan NIOSH dari 18 titik pengukuran metode noise mapping terdapat 8 titik dengan tingkat kebisingan >85 dB yang menunjukkan waktu pemaparan di atas standar yang sudah direkomendasikan NIOSH. Tingkat kebisingan tertinggi sebesar $92.9 \mathrm{~dB}$ dengan lama pemaparan selama 0.011 jam $(0,67$ menit) dan tingkat kebisingan terendah sebesar $83 \mathrm{~dB}$ dengan lama pemaparan selama 640 menit $(10,67$ jam). Upaya pengendalian kebisingan dapat melibatkan tiga elemen yaitu sumber kebisingan, lintasan rambatan kebisingan dan penerima kebisingan.
\end{abstract}

Kata Kunci : NIOSH; Pemetaan Kebisingan; Surfer 16

\section{Abstract}

Operational activities of PT.Y is engaged in the production of Fatty Alcohol, potentially generating the noise obtained from machines in the manufacture of Fatty Alcohol. Noise that occurs in the production area affects the health and comfort of the operator while working. This study aims to determine the noise level, duration of exposure, noise exposure area and analysis of the causes of noise and the proposed noise control on the production floor. The noise measurement method refers to the noise mapping method and the instrument sound level meter. The data obtained is the processed into a contour map with variations in green, yellow, orange and red through Surfer 16 Software. The results showed that the highest noise level was $92.9 \mathrm{~dB}$ and the lowest noise level was $83.0 \mathrm{~dB}$. Based on the results of calculation using the NIOSH equation from 18 measurement point of the noise mapping method, there are 8 point with noise level of $>85 \mathrm{~dB}$ which indicates the exposure time is above the standard recommended by NIOSH. The highest noise level is $92.9 \mathrm{~dB}$ with an exposure time of 0.011 hours (0.67 minutes) and the lowest noise level is $83 \mathrm{~dB}$ with an exposure time of 640 minutes (10.67 hours). Noise control efforts can involve three elements, namely the noise source, the propagation path and the noise receiver.

Keywords : NIOSH; Noise Mapping; Surfer 16

How to Cite: Andri Silviana, Nukhe \& Ninny Siregar (2021). Pengukuran dan Pemetaan Tingkat Kebisingan Pada Area Produksi. JIME (Journal of Industrial and Manufacture Engineering). 5(2): 161 166 


\section{PENDAHULUAN}

Kebisingan merupakan masalah yang sering kita jumpai di berbagai area industri. Dalam suatu perusahaan industri penggunaan mesin dan alat kerja mendukung proses produksi dan berpotensi menimbulkan kebisingan yang disebabkan oleh suara mesin, mesin tua, getaran mesin $(\mathrm{Hz})$, saluran pembuangan pada mesin.

Tingkat kebisingan yang melebihi nilai ambang batas dapat mendorong timbulnya gangguan pendengaran dan resiko kerusakan pada telinga baik bersifat sementara maupun permanen setelah terpapar dalam periode waktu tertentu tanpa penggunaan alat proteksi yang memadai. Potensi resiko ini mendorong pemerintah diberbagai negara membuat suatu regulasi yang membatasi eskposur suara pekerja industri.

Pabrik PT. Y, merupakan salah satu perusahaan yang bergerak dalam bidang produksi Fatty Alcohol. Dalam menunjang proses produksi guna memenuhi tuntutan peningkatan produktivitas dan penurunan tenaga kerja, maka pabrik PT.Y telah menerapkan sistem mekanisasi pada alat dan mesin industri yang berpotensi menimbulkan kebisingan. Kebisingan yang berasal dari mesin disertai suara yang keras terus menerus akan meningkatkan pemaparan suara pada tenaga kerja sehingga menambah resiko bahaya terhadap tenaga kerja.

Pada peraturan pemerintahan Indonesia terhadap kawasan industri yaitu nilai ambang batas (NAB) kebisingan yang diperoleh sebesar $85 \mathrm{~dB}$ dalam pemaparan selama 8 (delapan) jam sehari dan 5 (hari) kerja atau 40 jam kerja dalam seminggu, hal ini merupakan ketentuan standar pedoman pengendalian agar tenaga kerja masih dapat menerimanya tanpa mengakibatkan penyakit atau gangguan kesehatan seperti gangguan fisiologis, gangguan psikologis, gangguan komunikasi, dan efek pada pendengaran dalam pekerjaan sehari-hari. NAB kebisingan yang tertera merupakan ketentuan dalam Peraturan Menteri Tenaga Kerja dan Transmigasi Republik Indonesia Nomor PER.13/MEN/X/2011 tentang nilai Ambang Batas di tempat kerja dan merupakan Standar Nasional Indonesia (SNI) 16-7063-2004 Nilai Ambang Batas iklim kerja (panas), kebisingan, getaran tangan-lengan dan radiasi ultra ungu ditempat kerja (Suma'mur, 2009).

Permasalahan kebisingan yang terdapat di bagian produksi pembuatan Fatty Alcohol, yaitu setelah dilakukan pengukuran awal diketahui bahwa tingkat kebisingan area lantai produksi berkisar $93 \mathrm{~dB}$. Dapat diketahui bahwa nilai ini melebihi nilai ambang batas kebisingan yang diizinkan pada peraturan pemerintah Indonesia terhadap kawasan industri yaitu nilai ambang batas (NAB) kebisingan yang diperbolehkan yaitu 85 (NAB). Dengan adanya permasalahan yang terjadi berkaitan dengan kebisingan, diketahui bahwa kebisingan diluar NAB yang terjadi secara terus menerus disebabkan oleh lingkungan kerja sehingga dapat menimbulkan gangguan kesehatan sehingga mengakibatkan hilangnya daya dengar yang tetap untuk waktu kerja secara terus menerus, maka perlu dilakukan identifikasi tingkat kebisingan pada area produksi. Data yang diperoleh dapat dipakai sebagai bahan pertimbangan analisis menyangkut hal-hal yang 
berkaitan dengan upaya pengendalian kebisingan dan guna melindungi pekerjaaan akibat paparan kebisingan.

Penyelesaian masalah ini perlu dilakukan suatu pemetaan tingkat kebisingan berdasarkan metode noise mapping. Noise mapping ialah pemetaan kebisingan yang menggambarkan pola tingkat kebisingan pada suatu lingkup area produksi. Dalam bidang industri biasanya noise mapping digunakan untuk memprediksi pola distribusi kebisingan di sekitar pabrik, yang bertujuan untuk merancang langkah-langkah untuk mengontrol dan mengurangi penyebaran kebisingan dan dengan demikian memenuhi undang-undang kebisingan yang berlaku (Casas et all, 2014).

Tujuan penelitian ini adalah mengukur tingkat kebisingan yang ditimbulkan oleh mesin produksi diarea produksi, Memetakan tingkat kebisingan dengan program surfer 16. Menganalisa perbandingan tingkat kebisingan yang terjadi di area produksi dengan baku mutu tingkat kebisingan Peraturan Menteri Tenaga Kerja Dan Transmigrasi Republik Indonesia Nomor 13 tahun 2011, Melakukan perhitungan waktu maksimal pemaparan terhadap tingkat kebisingan yang ditimbulkan berdasarkan metode perhitungan NIOSH, Serta Merekomendasikan pengendalian aspek kebisingan berdasarkan peta persebaran kebisingan di area produksi.

\section{METODE PENELITIAN}

\section{Instrumen Penelitian}

Dalam Penelitian ini instrumen penelitian yang akan dipakai adalah:

1. Sound Level Meter manual yang mempunyai rentang pengukuran 35

- $130 \mathrm{~dB}$ untuk mengukur tingkat kebisingan. Alat ini juga dilengkapi alat pengukur arah angin, kelembapan, suhu dan kecepatan angin.

2. Software Surfer 16 untuk membuat kontur kebisingan.

3. Global Positioning System (GPS) untuk menentukan koordinat lokasi pengukuran.

4. Alat ukur panjang jarak/meteran untuk mengukur jarak grid di lapangan.

\section{Metode Pengukuran Kebisingan}

Penentuan area pengukuran kebisingan pada PT. Y sebanyak 18 titik pengukuran. Alat yang digunakan dalam pengukuran kebisingan ialah sound level meter.

Setiap pengukuran harus dapat mewakili selang waktu tertentu dalam 1 shift kerja dengan penetapannya sebagai berikut :

1. L1 diambil pada jam 08.00 mewakili jam 06.00 - 09.00

2. L2 diambil pada jam 09.00 mewakili jam 09.00 - 11.00

3. L3 diambil pada jam 15.00 mewakili jam $14.00-17.00$

\section{Metode Perhitungan Tingkat Kebisingan Pemaparan Maksimal yang diijinkan}

Adapun perhitungan lama pekerja terpapar kebisingan dihitung dengan metode (NIOSH, 1998). Dengan menggunakan persamaan berikut:

$$
\mathrm{T}=\frac{480}{2^{(L-85) / 3}}
$$

Dimana :

$\mathrm{T} \quad$ = lama pemaparan maksimal yang dijinkan pada titik tersebut (menit) 
$\mathrm{L}=$ tingkat kebisingan pada titik tersebut.

\section{HASIL DAN PEMBAHASAN}

\section{Identifikasi Sumber Bising}

Dari hasil pengukuran kebisingan area produksi, diketahui bahwa sumber suara bising yang ada berasal dari proses kerja mesin - mesin produksi yang digunakan untuk pengerjaan Fatty Alcohol. Sumber bising dapat dilihat pada Tabel 1 .

Tabel 1. Identifikasi Sumber Bising

\begin{tabular}{|c|c|c|}
\hline No & Lokasi & Sumber Bising \\
\hline 1 & Area A & $\begin{array}{l}\text { Pengoperasian unit } \\
\text { Fraksinasi dan Destilasi } \\
\text { Pengoperasian unit } \\
\text { Hydrogen }\end{array}$ \\
\hline 2 & Area B & $\begin{array}{l}\text { Generation/Mahler } \\
\text { Pengoperasian unit }\end{array}$ \\
\hline 3 & Area C & $\begin{array}{l}\text { Carbonil Conversion } \\
\text { Pengoperasian unit Wax }\end{array}$ \\
\hline 4 & Area D & Ester Preperation \\
\hline 5 & Area E & $\begin{array}{l}\text { Pengoperasian unit OTH } \\
\text { burner }\end{array}$ \\
\hline 6 & Area $\mathrm{F}$ & $\begin{array}{l}\text { Pengoperasian unit Wax } \\
\text { Ester Hydrogenation }\end{array}$ \\
\hline
\end{tabular}

\section{Pengukuran Tingkat Kebisingan dengan Metode Grid}

Setelah dilakukan pengukuran pada setiap titik didapatkan nilai kebisingan rata-rata pada titik tersebut. Hasil Pengukuran tingkat kebisingan dapat dilihat pada Tabel 2 berikut:

Tabel 2. Hasil Pengukuran Tingkat Kebisingan

\begin{tabular}{lll}
\hline Titik & Tingkat & \\
Pengukuran & Kebisingan & Keterangan \\
\hline 1,2 dan 3 & $85,7 \mathrm{~dB}-88 \mathrm{~dB}$ & Pada titik ini \\
\hline
\end{tabular}

\begin{tabular}{|c|c|c|}
\hline & $\begin{array}{l}\text { (Melebihi } \\
\text { baku mutu } \\
\text { Peraturan } \\
\text { Menteri Tenaga } \\
\text { Kerja } \\
\text { No.13 Tahun } \\
\text { 2011) }\end{array}$ & $\begin{array}{l}\text { merupakan } \\
\text { sumber } \\
\text { bising dan } \\
\text { area } \\
\text { yang sangat } \\
\text { berbaya bagi } \\
\text { pekerja. }\end{array}$ \\
\hline 4,5 dan 6 & $\begin{array}{l}\text { 86, } 1 \mathrm{~dB}-86,7 \mathrm{~dB} \\
\text { ( Tidak melebihi } \\
\text { baku mutu } \\
\text { Peraturan } \\
\text { Menteri Tenaga } \\
\text { Kerja } \\
\text { No.13 Tahun } \\
\text { 2011) }\end{array}$ & $\begin{array}{l}\text { Titik } \\
\text { tersebut } \\
\text { berjarak } \\
\text { dekat } \\
\text { dengan } \\
\text { mesin mesin. }\end{array}$ \\
\hline 7,8 dan 9 & $\begin{array}{l}\text { 86,1 dB -92,9 dB } \\
\text { (melebihi } \\
\text { baku mutu } \\
\text { Peraturan } \\
\text { Menteri Tenaga } \\
\text { Kerja } \\
\text { No.13 Tahun } \\
\text { 2011) } \\
\end{array}$ & $\begin{array}{l}\text { Pada titik ini } \\
\text { merupakan } \\
\text { sumber } \\
\text { bising dan } \\
\text { area } \\
\text { yang sangat } \\
\text { berbaya bagi } \\
\text { pekerja. } \\
\end{array}$ \\
\hline 10 dan 11 & $\begin{array}{l}87,4 \mathrm{~dB}-89,9 \mathrm{~dB} \\
\text { (melebihi } \\
\text { baku mutu } \\
\text { Peraturan } \\
\text { Menteri Tenaga } \\
\text { Kerja } \\
\text { No.13 Tahun } \\
\text { 2011) }\end{array}$ & $\begin{array}{l}\text { Pada titik ini } \\
\text { merupakan } \\
\text { sumber } \\
\text { bising dan } \\
\text { area } \\
\text { yang sangat } \\
\text { berbaya bagi } \\
\text { pekerja. }\end{array}$ \\
\hline $\begin{array}{l}12, \quad 13,14, \\
\text { dan } 15\end{array}$ & $\begin{array}{l}84,6 \mathrm{~dB}-85,7 \mathrm{~dB} \\
\text { (Tidak } \\
\text { baku mutu } \\
\text { Peraturan } \\
\text { Menteri Tenaga } \\
\text { Kerja } \\
\text { No.13 Tahun } \\
\text { 2011) } \\
\end{array}$ & $\begin{array}{l}\text { Titik } \\
\text { tersebut } \\
\text { berjarak } \\
\text { dekat } \\
\text { dengan } \\
\text { mesin mesin. }\end{array}$ \\
\hline $\begin{array}{l}16,17 \text { dan } \\
18\end{array}$ & $\begin{array}{l}83 \mathrm{~dB}-85,7 \mathrm{~dB} \\
\text { (Tidak } \\
\text { baku mutu } \\
\text { Peraturan } \\
\text { Menteri Tenaga } \\
\text { Kerja } \\
\text { No.13 Tahun } \\
2011 \text { ) } \\
\end{array}$ & $\begin{array}{l}\text { Titik } \\
\text { tersebut } \\
\text { berjarak } \\
\text { dekat } \\
\text { dengan } \\
\text { mesin mesin. }\end{array}$ \\
\hline \multicolumn{3}{|c|}{$\begin{array}{l}\text { Dari hasil pengukuran kebisingan } \\
\text { dilakukan pengolahan data menggunakan } \\
\text { Software Surfer } 13 \text {. Pola sebaran tingkat }\end{array}$} \\
\hline
\end{tabular}


kebisingan di kelompokkan sebagai berikut :

1. Warna hijau menggambarkan tingkat kebisingan $83 \mathrm{~dB}-84 \mathrm{~dB}$.

2. Warna kuning menggambarkan tingkat kebisingan $85 \mathrm{~dB}-86 \mathrm{~dB}$.

3. Warna kuning tua menggambarkan tingkat kebisingan $87 \mathrm{~dB}-89 \mathrm{~dB}$.

4. Warna orange menggambarkan tingkat kebisingan $90 \mathrm{~dB}$.

5. Warna merah menggambarkan tingkat kebisingan $>92 \mathrm{~dB}$.

Berikut adalah pemetaan tingkat kebisingan diarea produksi.

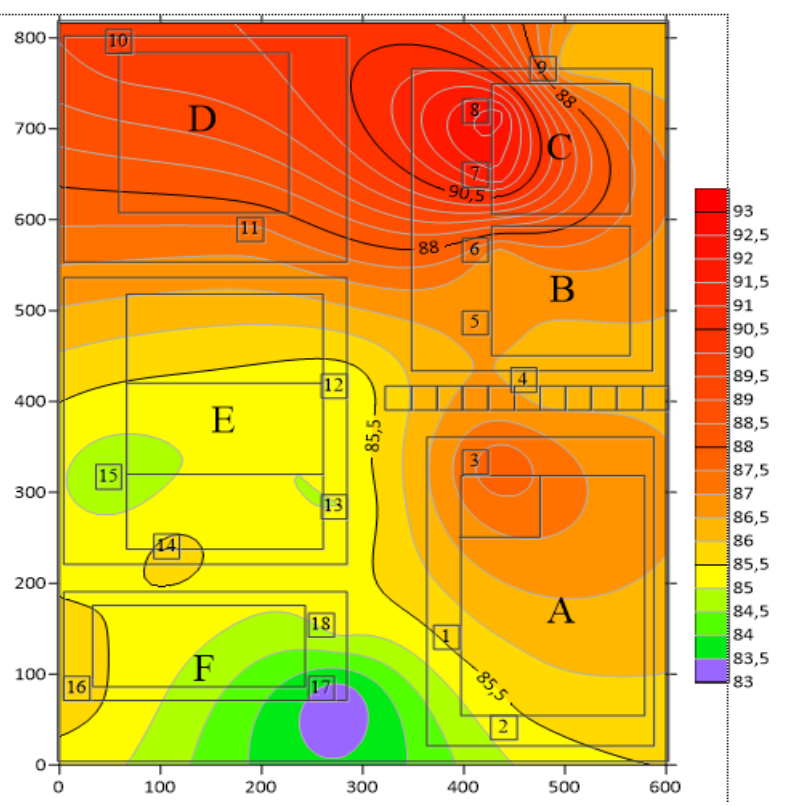

Gambar 1. Pemetaan Sebaran Kebisingan

\section{Analisis Waktu Pemaparan Menggunakan Rumus NIOSH}

Berdasarkan pemetaan tingkat kebisingan di area produksi, maka dilakukan perhitungan pada titik pengukuran yang dikelompokkan berdasarkan intensitas tingkat kebisingan melebihi ambang baku mutu ( $>85 \mathrm{~dB}$ ) dan intensitas tingkat kebisingan tidak melebihi ambang baku mutu $(<85 \mathrm{~dB})$ Peraturan Menteri Tenaga Kerja No.13 Tahun 2011 dan untuk menentukan lama pemaparan kebisingan yang diperbolehkan maka digunakan metode perhitungan NIOSH.

Dilakukan perhitungan $\mathrm{NIOSH}$, pada titik yang tingkat kebisingannya tidak melebihi ambang baku mutu ( $<85 \mathrm{~dB}$ ) yaitu titik 12 dengan tingkat kebisingan $83 \mathrm{~dB}$ sebagai berikut :

$$
\begin{aligned}
\mathrm{T} & =\frac{480}{2^{(L-85) / 3}}=\frac{480}{2^{(83-85) / 3}} \\
& =640 \text { menit }=10.67 \mathrm{jam}
\end{aligned}
$$

Berdasarkan perhitungan terlihat pada titik 12 tersebut pekerja terpaparan kebisingan berturut-turut paling lama adalah selama 10.67 Jam, jika tidak menggunakan APD atau upaya pengurangan kebisingan. Nilai ini dinyatakan aman, mengingat pekerja hanya bekerja 8 jam sehari.

Untuk titik yang melebihi ambang baku mutu (>85 dB) yaitu titik 9 dengan tingkat kebisingan $92.9 \mathrm{~dB}$ sebagai berikut:

$$
\begin{aligned}
\mathrm{T}=\frac{480}{2^{(L-85) / 3}}=\frac{480}{2^{(92.9-85) / 3}} \\
=0.67 \text { menit }=0.011 \mathrm{jam}
\end{aligned}
$$

Pada titik 9, pada titik tersebut pekerja terpaparan kebisingan berturutturut paling lama adalah selama 0.67 menit, jika tidak menggunakan APD atau upaya pengurangan kebisingan. Titik 12 merupakan titik dengan kebisingan tertinggi, karena titik tersebut jaraknya sangat dekat dengan mesin yang sedang beroperasi. Titik yang tingkat kebisingan yang melebihi baku mutu kebisingan sehingga lama waktu pemaparan yang diperbolehkan kurang dari 8 jam kerja. Pada titik-titik ini diperlukan penanganan lebih lanjut walaupun waktu pemaparan 
tidak terlalu tinggi sehingga tidak menyebabkan penyakit akibat kerja, khususnya resiko kerusakan atau gangguan pendengaran yang disebabkan oleh waktu terpapar kebisingan yang melebihi standar.

\section{Solusi Pengendalian Kebisingan}

Upaya pengendalian kebisingan dapat melibatkan tiga elemen yaitu sumber kebisingan, lintasan rambatan kebisingan dan penerima kebisingan, ketiga ini saling berkaitan sehingga pengetahuan akan ketiga elemen ini sangat diperlukan sebelum mencoba menyelesaikan masalah kebisingan. Dalam upaya pengendalian kebisingan di lingkungan pabrik agar lebih efektif, maka perlu dilakukan identifikasi masalah kebisingan di pabrik, dan menentukan tingkat kebisingan yang diterima oleh karyawan. Data yang diperoleh dapat dipakai sebagai bahan analisis hal-hal yang berkaitan dengan upaya mengurangi kebisingan secara teknis di sumber suara adalah cara yang paling efektif untuk mengurangi tingkat kebisingan. Selain itu juga pengendalian kebisingan dapat ditempuh secara administratif dengan cara mengatur pola kerja

\section{SIMPULAN}

Kesimpulan yang dapat diambil dari penelitian ini adalah :

1. Berdasarkan hasil pengukuran dilapangan terdapat 18 titik kebisingan tertinggi yang berada diatas baku mutu tingkat kebisingan Peraturan Menteri Tenaga Kerja Dan Transmigrasi Republik Indonesia Nomor Per.13/Men/X/2011 sebelum dilakukan pengendalian. Untuk titik kebisingan yang paling tertinggi adalah 92,9 dB pada titik 9 .
2. Berdasarkan pengukuran tingkat kebisingan pada setiap titik, maka waktu lama pemaparan yang direkomendasikan oleh NIOSH bervariasi, dan tergantung dari hasil pengukuran yang didapat. Waktu pemaparan paling tinggi yang diperbolehkan yaitu pada titik 9 dengan waktu pemaparan 0.67 menit dikarenakan titik pengukuran ini berada paling dekat dengan sumber bising.

3. Upaya pengendalian kebisingan dapat melibatkan tiga elemen yaitu sumber kebisingan, lintasan rambatan kebisingan dan penerima kebisingan.

\section{DAFTAR PUSTAKA}

Ahmad, F. dkk. 2018. Analisis Tingkat Kebisingan di Universitas Semarang dengan Peta Kontur Menggunakan Sofware Surfer Golden 14.Jurnal

Casas, WJP., Cordeiro, EP., Mello, TC and Zannin, PHT. 2014. Noise mapping as a tool for controlling industrial noise pollution. Journal of Scientific \& Industrial Research Vol. 73, April 2014, pp. 262-266

Fithri, P. dkk. 2015. Analisis Intensitas Kebisingan Lingkungan Kerja pada Area Utilities Unit PLTD dan Boiler di PT. Pertamnina RU II Dumai. Jurnal

Fredianta G. D, dkk. 2013. Analisis Tingkat Kebisingan Untuk Mereduksi Dosis Paparan Kebisingan di PT. XYZ. Jurnal

Tarwaka 2011. Dasar-Dasar Pengetahuan Ergonnomi Dan Aplikasi Di Tempat Kerja, Surakarta. Jurnal

Luxson, M. Dkk. 2012. Kebisingan di Tempat Kerja, Jurnal Program Pasca Sarjana Kesehatan Masyarakat, STIK Bina Husada, Palembang. Jurnal

Ginting, R. 2007. Sistem Produksi. Jakarta: Gramedia Keputusan Menteri Nagara Lingkungan Hidup. 1996. Baku Tingkat Kebisingan, Surat Keputusan Menteri Negara Linkungan Hidup No: Kep48/Menlh/1996/25 November 1996, Jakarta : Meneg $\mathrm{LH}$

Keputusan Menteri Tenaga Kerja dan Transmigasi Republik Indonesia Nomor PER.13/MEN/X/2011. Nilai Ambang Batas Faktor Fisika dan Faktor Kimia.

Ngadiyono,Y. 2010. Buku Pemeliharaan Mekanik Industri. Kementrian Pendidikan Nasional 
Nukhe Andri Silviana \& Ninny Siregar. Pengukuran dan Pemetaan Tingkat Kebisingan Pada Area Produksi.

Universitas Negeri Yogyakarta Program Studi Pendidikan Teknik Mesin.

Pohan, S. 2014. Analisis Tingkat Kebisingan Pada Lantai Produksi Dengan Metode Pola Sebaran Pemetaan Kebisingan (Studi Kasus: PT. Agro Sarimas Indonesia. Jurnal
Purnomo, H. 2014. Pengantar Teknik Industri.Yogyakarta: Graha Ilmu

Sinulingga, S. 2011. Metode Penelitian. Yogyakarta : Penerbit Graha Ilmu. 